\title{
Small Business Survival Index Traction And Movement In Rankings Of States (2000-2013)
}

P. K. Shukla, Chapman University, USA

Monica P. Shukla, Chapman University, USA

\begin{abstract}
Given the economic climate faced domestically in the United States since 2008, there is a desire by politicians to increase state economic and business growth. As small businesses are the main driver of business growth in state economies, focus should be placed upon the policy environment of a state to encourage state level growth in entrepreneurial activities aimed at small business creation and survival.
\end{abstract}

The Small Business and Entrepreneurship Council (SBE Council) - a 501c(4) advocacy, research, training and networking organization dedicated to protecting small business and promoting entrepreneurship - has annually prepared a "Small Business Survival Index" that ranks states according to some of the major government-imposed or government-related costs affecting investment, entrepreneurship, and business.

This study presents the results from an analysis of the rankings of states on the Small Business Survival Index from 2000 to 2013 which focused on three categories of states - overall ranking gainer states, those that are stable in ranking, and overall ranking decliner states, the percentage in each category, and conclusions. The paper also includes a rank correlation analysis of various periods of time to measure the extent of traction and mobility in the SBSI state rankings from 2000 to 2013. As states vary by governor length of years in their governor term and also by term limits or not on governor terms allowed, there is an analysis of impact of governor years of term on changes in SBSI ranking and an analysis of impact of governor term limits on changes in SBSI ranking.

Keywords: Small Businesses; Small Business Survival Index; Promoting Entrepreneurship; Government Policy

\section{INTRODUCTION}

iven the economic climate faced domestically in the United States since 2008, combined with on-going budgetary constraints at the Federal and most State levels of government, there is a desire by state politicians to increase state economic and business growth. Business growth at the state level is good for increasing state employment, increasing state household/business income, increasing state level household consumption, and in raising state tax revenue. Given the fact that small businesses are the main driver of business growth in state economies, focus should be placed upon the policy environment of a state to encourage state-level growth in entrepreneurial activities aimed at small business creation and small business survival.

During state elections, state politicians often claim that they are in favor of change, reform, and in helping to stimulate business and entrepreneurship growth once elected. If such political efforts were effective at the state level, one would expect that a state should improve in its ranking on rankings that examine state-level small business survival levels over various extended periods of time. 
"The Small Business and Entrepreneurship Council (SBE Council) is a 501c(4) advocacy, research, training and networking organization dedicated to protecting small business and promoting entrepreneurship. The SBE Council works to educate elected officials, policymakers, business leaders and the public about key policies that enable business start-up and growth. Through advocacy, research, media outreach, training, and education, SBE Council members and staff convey the importance of entrepreneurship to job creation, innovation, economic growth and U.S. competitiveness. The SBE Council is viewed as one of the most powerful and effective organizations dedicated to protecting small business and promoting entrepreneurship." (www.sbecouncil.org)

Since 1995, the SBE Council has annually prepared a "Small Business Survival Index" (renamed "Business Tax Index" in 2013) in which the report ranks the 50 states and the District of Columbia according to some of the major government-imposed or government-related costs affecting investment, entrepreneurship, and business. The Small Business Survival Index ("SBSI") ranks the states according to their policy climates for entrepreneurship. The Small Business \& Entrepreneurship Council's "Business Tax Index 2013" (previously called SBSI) ranks the states from best to worst in terms of the costs of their tax systems on entrepreneurship and small business. The 2013 edition of the Index pulls together 21 different tax measures and combines those into one tax score that allows the 50 states to be compared and ranked (Keating, 2013).

The 21 measures of the SBSI are: 1) state's top personal income tax rate, 2) state's top individual capital gains tax rate, 3) state's top tax rate on dividends and interest, 4) state's top corporate income tax rate, 5) state's top corporate capital gains tax rate, 6) any added income tax on S-Corporations, 7) whether or not the state imposes an alternative minimum tax on individuals, 8) whether or not the state imposes an alternative minimum tax on corporations, 9) whether or not the state's personal income tax brackets are indexed for inflation, 10) the progressivity of the state's personal income tax brackets, 11) the progressivity of the state's corporate income tax brackets, 12) property taxes, 13) consumption-based taxes (i.e., sales, gross receipts, and excise taxes), 14) whether or not the state imposes a death tax, 15) unemployment taxes, 16) whether or not the state has a tax limitation mechanism, 17) whether or not the state imposes an Internet access tax, 18) “Amazon" taxes, 19) gas tax, 20) diesel tax, and 21) wireless taxes (Keating, 2013).

This study presents the results from an analysis of the rankings of states on the Small Business Survival Index from 2000 to 2013 which focused on three categories of states: 1) those that remained relatively stable in their rank (defined as same rank or +/- a slight change in ranking; +3 to -3 overall change in ranking from 2000 to 2013), 2) those who significantly improved in their ranking (a significant improvement is defined as a +4 or more increase in overall ranking from 2000 to 2013), and 3) those who significantly decreased in their ranking (a significant decrease is defined as a -4 or more decrease in overall ranking from 2000 to 2013). Table 1 displays a rank-ordered listing of the 50 states (excluding the District of Columbia) based upon their overall change in SBSI rank from 2000 to 2013, and it also displays the yearly rank of each state from 2000 to 2013.

\section{CHANGES IN OVERALL SBSI RANKING}

This paper identifies the nominal number in each of the three categories - overall gainer states, those that are stable, and overall decliner states, the percentage in each category, and overall conclusions. The paper also includes a rank correlation analysis of various periods of time to measure the extent of traction (little to no change in ranking) and mobility in the SBSI state rankings from 2000 to 2013. As states vary by governor length of years in their governor term and also by term limits or not on governor terms allowed, there is an analysis of impact of governor years of term on changes in SBSI ranking and an analysis of impact of governor term limits on changes in SBSI ranking.

Table 1 displays the changes in overall SBSI ranking of each state from 2000 to 2013 . The table displays the following results on the breakdown of states into the three categories based upon overall change in rank over the thirteen year period of 2000 to 2013:

- $\quad 11$ states significant gainers (+4 or more increase 2000 to 2013); see Table 1 for State names

- 19 states no significant change (+3 to -3 change 2000 to 2013); see Table 1 for State names

- 20 states significant decliners (-4 or more decrease 2000 to 2013); see Table 1 for State names 
Table 1: State Rankings on Small Business Survival Index from 2000 to 2013 Sorted by Level of Rank Change

\begin{tabular}{|c|c|c|c|c|c|c|c|c|c|c|c|c|c|c|c|c|c|c|}
\hline 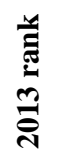 & 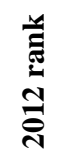 & 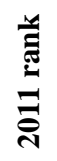 & 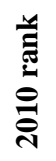 & 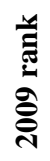 & 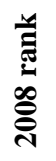 & 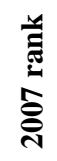 & 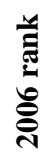 & 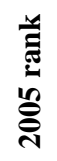 & 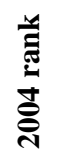 & 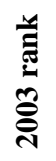 & 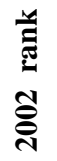 & 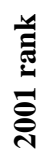 & 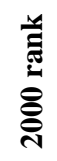 & 营 & $\begin{array}{l}8 \\
\dot{8} \\
\ddot{z}\end{array}$ & $\begin{array}{l}8 \\
\dot{\partial} \\
\ddot{z}\end{array}$ & $\begin{array}{l}8 \\
\dot{8} \\
\dot{8}\end{array}$ & 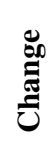 \\
\hline 9 & 18 & 7 & 9 & 11 & 18 & 29 & 38 & 40 & 40 & 39 & 40 & 40 & 46 & Ohio & 37 & 29 & 8 & 1 \\
\hline 27 & 26 & 28 & 25 & 28 & 29 & 25 & 29 & 33 & 36 & 43 & 47 & 45 & 48 & New Mexico & 21 & 2 & 19 & 2 \\
\hline 12 & 8 & 14 & 12 & 14 & 15 & 18 & 26 & 30 & 28 & 26 & 27 & 34 & 33 & Utah & 21 & 14 & 7 & 3 \\
\hline 30 & 32 & 30 & 33 & 31 & 33 & 35 & 30 & 38 & 38 & 38 & 38 & 38 & 45 & Montana & 15 & 0 & 15 & 4 \\
\hline 25 & 28 & 23 & 29 & 26 & 31 & 30 & 35 & 31 & 31 & 32 & 32 & 47 & 36 & Kansas & 11 & 10 & 1 & 5 \\
\hline 13 & 10 & 15 & 13 & 16 & 13 & 15 & 15 & 17 & 17 & 18 & 20 & 20 & 23 & Arizona & 10 & 2 & 8 & 6 \\
\hline 39 & 41 & 47 & 45 & 45 & 47 & 48 & 48 & 48 & 48 & 47 & 45 & 50 & 49 & Rhode Island & 10 & 9 & 1 & 7 \\
\hline 22 & 23 & 19 & 21 & 21 & 21 & 21 & 23 & 29 & 30 & 27 & 26 & 28 & 31 & Oklahoma & 9 & 1 & 8 & 8 \\
\hline 8 & 9 & 9 & 10 & 8 & 10 & 11 & 8 & 10 & 9 & 12 & 12 & 11 & 16 & Colorado & 8 & 0 & 8 & 9 \\
\hline 43 & 40 & 43 & 42 & 43 & 46 & 45 & 46 & 47 & 47 & 49 & 48 & 46 & 47 & Minnesota & 4 & 3 & 1 & 10 \\
\hline 1 & 3 & 3 & 3 & 3 & 6 & 7 & 9 & 11 & 11 & 6 & 4 & 6 & 5 & Texas & 4 & 8 & -4 & 11 \\
\hline 38 & 37 & 37 & 38 & 39 & 39 & 39 & 40 & 39 & 37 & 37 & 37 & 35 & 41 & North Carolina & 3 & 2 & 1 & 12 \\
\hline 10 & 19 & 21 & 15 & 12 & 16 & 17 & 17 & 21 & 20 & 22 & 21 & 14 & 12 & Alaska & 2 & 7 & -5 & 13 \\
\hline 16 & 25 & 26 & 27 & 29 & 27 & 31 & 33 & 35 & 32 & 21 & 18 & 19 & 18 & Louisiana & 2 & 17 & -15 & 14 \\
\hline 42 & 43 & 34 & 39 & 38 & 32 & 34 & 39 & 37 & 39 & 42 & 36 & 36 & 44 & Oregon & 2 & -3 & 5 & 15 \\
\hline 5 & 6 & 11 & 5 & 5 & 5 & 4 & 5 & 4 & 4 & 8 & 6 & 3 & 7 & Washington & 2 & 0 & 2 & 16 \\
\hline 7 & 7 & 6 & 7 & 9 & 8 & 10 & 4 & 8 & 8 & 11 & 10 & 8 & 8 & Alabama & 1 & -3 & 4 & 17 \\
\hline 49 & 45 & 39 & 44 & 42 & 41 & 42 & 44 & 46 & 49 & 50 & 50 & 49 & 50 & Hawaii & 1 & -5 & 6 & 18 \\
\hline 23 & 24 & 35 & 30 & 27 & 25 & 24 & 16 & 14 & 12 & 17 & 17 & 22 & 24 & Pennsylvania & 1 & -7 & 8 & 19 \\
\hline 6 & 5 & 8 & 6 & 6 & 4 & 5 & 6 & 6 & 5 & 5 & 5 & 5 & 6 & Florida & 0 & 0 & 0 & 20 \\
\hline 28 & 30 & 32 & 35 & 36 & 40 & 40 & 37 & 34 & 33 & 40 & 41 & 41 & 28 & West Virginia & 0 & 9 & -9 & 21 \\
\hline 3 & 2 & 2 & 2 & 2 & 2 & 2 & 2 & 2 & 2 & 2 & 2 & 1 & 2 & Nevada & -1 & -1 & 0 & 22 \\
\hline 2 & 1 & 1 & 1 & 1 & 1 & 1 & 1 & 1 & 1 & 1 & 1 & 2 & 1 & South Dakota & -1 & -1 & 0 & 23 \\
\hline 18 & 12 & 10 & 14 & 10 & 9 & 9 & 14 & 13 & 15 & 14 & 14 & 15 & 17 & Virginia & -1 & -4 & 3 & 24 \\
\hline 4 & 4 & 4 & 4 & 4 & 3 & 3 & 3 & 3 & 3 & 3 & 3 & 4 & 3 & Wyoming & -1 & -1 & 0 & 25 \\
\hline 36 & 34 & 18 & 24 & 25 & 30 & 27 & 20 & 16 & 24 & 25 & 24 & 25 & 34 & Arkansas & -2 & -16 & 14 & 26 \\
\hline 11 & 11 & 29 & 26 & 23 & 19 & 6 & 10 & 5 & 6 & 9 & 11 & 12 & 9 & Michigan & -2 & -1 & -1 & 27 \\
\hline 17 & 14 & 5 & 8 & 7 & 7 & 8 & 11 & 12 & 13 & 16 & 16 & 18 & 15 & South Carolina & -2 & -6 & 4 & 28 \\
\hline 45 & 46 & 45 & 46 & 46 & 48 & 47 & 47 & 49 & 46 & 48 & 49 & 48 & 42 & Maine & -3 & 2 & -5 & 29 \\
\hline 32 & 27 & 24 & 31 & 30 & 26 & 33 & 27 & 27 & 27 & 31 & 31 & 30 & 29 & Wisconsin & -3 & -5 & 2 & 30 \\
\hline 29 & 29 & 22 & 22 & 22 & 23 & 22 & 36 & 28 & 29 & 28 & 29 & 32 & 25 & Kentucky & -4 & 7 & -11 & 31 \\
\hline 31 & 38 & 42 & 43 & 44 & 44 & 44 & 43 & 42 & 41 & 30 & 30 & 21 & 27 & Massachusetts & -4 & 12 & -16 & 32 \\
\hline 14 & 15 & 12 & 16 & 19 & 17 & 16 & 7 & 7 & 7 & 10 & 9 & 9 & 10 & Mississippi & -4 & -7 & 3 & 33 \\
\hline 44 & 47 & 50 & 49 & 48 & 45 & 46 & 45 & 44 & 45 & 45 & 43 & 43 & 40 & York & -4 & 1 & -5 & 34 \\
\hline 24 & 16 & 13 & 18 & 17 & 22 & 20 & 24 & 26 & 26 & 33 & 35 & 24 & 20 & North Dakota & -4 & 0 & -4 & 35 \\
\hline 15 & 17 & 25 & 11 & 13 & 11 & 13 & 13 & 15 & 16 & 7 & 8 & 10 & 11 & Tennessee & -4 & -2 & -2 & 36 \\
\hline 26 & 21 & 16 & 20 & 20 & 12 & 12 & 25 & 22 & 22 & 23 & 22 & 23 & 21 & Georgia & -5 & -1 & -4 & 37 \\
\hline 37 & 31 & 27 & 34 & 32 & 35 & 36 & 34 & 19 & 25 & 29 & 28 & 26 & 32 & Idaho & -5 & -3 & -2 & 38 \\
\hline 48 & 49 & 49 & 50 & 50 & 50 & 50 & 50 & 45 & 44 & 36 & 39 & 37 & 43 & New Jersey & -5 & 2 & -7 & 39 \\
\hline 41 & 42 & 44 & 41 & 40 & 37 & 38 & 32 & 36 & 34 & 35 & 33 & 33 & 35 & Connecticut & -6 & -9 & 3 & 40 \\
\hline 19 & 13 & 20 & 17 & 15 & 20 & 14 & 12 & 9 & 10 & 15 & 15 & 16 & 13 & Indiana & -6 & -7 & 1 & 41 \\
\hline 21 & 22 & 17 & 19 & 18 & 14 & 19 & 22 & 18 & 18 & 19 & 19 & 17 & 14 & Missouri & -7 & 1 & -8 & 42 \\
\hline 35 & 33 & 31 & 32 & 35 & 34 & 32 & 19 & 24 & 23 & 20 & 23 & 29 & 26 & Delaware & -9 & -16 & 7 & 43 \\
\hline 47 & 44 & 41 & 40 & 41 & 42 & 41 & 41 & 41 & 43 & 41 & 44 & 39 & 38 & Iowa & -9 & -6 & -3 & 44 \\
\hline 46 & 48 & 48 & 47 & 47 & 43 & 43 & 42 & 43 & 42 & 44 & 42 & 42 & 37 & Vermont & -9 & -4 & -5 & 45 \\
\hline 40 & 39 & 36 & 37 & 34 & 36 & 37 & 31 & 32 & 35 & 34 & 34 & 31 & 30 & Nebraska & -10 & -9 & -1 & 46 \\
\hline 50 & 50 & 46 & 48 & 49 & 49 & 49 & 49 & 50 & 50 & 46 & 46 & 44 & 39 & California & -11 & -1 & -10 & 47 \\
\hline 34 & 36 & 38 & 36 & 37 & 38 & 28 & 28 & 25 & 21 & 24 & 25 & 27 & 22 & Maryland & -12 & -6 & -6 & 48 \\
\hline 33 & 35 & 40 & 28 & 24 & 24 & 26 & 21 & 23 & 19 & 13 & 13 & 13 & 19 & Illinois & -14 & -12 & -2 & 49 \\
\hline 20 & 20 & 33 & 23 & 33 & 28 & 23 & 18 & 20 & 14 & 4 & 7 & 7 & 4 & New Hampshire & -16 & -2 & -14 & 50 \\
\hline
\end{tabular}


The results for the 50 states show that $62 \%$ of the states display significant change and that movement is possible both upward (11 out of 50 states gainers: $22 \%$ ) and downward (20 out of 50 states decliners: $40 \%$ ). Despite the mobility displayed, a high percentage value remains at $38 \%$ of the states displaying no significant change from 2000 to 2013 (19 out of 50 states with an overall change in ranking on the SBSI no greater than a +3 gain or no more than -3 decline).

Although some level of change is displayed as possible at improving state ranking on the SBSI over thirteen years, sustained gains over two different long-term time periods ( 6 years - from 2000 to 2006 - followed by 7 years - from 2006 to 2013) is even more difficult. Only nine states out of $50(18 \%)$ showed sustained gains $(+1$ or more gain in rank during both periods 2000 to 2006 and 2006 to 2013). The majority of states - 30 out of 50 (60\%) displayed no sustained change during both time periods. Again, the data displays that downward mobility in ranking is more common than upward mobility as 11 out of $50(22 \%)$ states displayed sustained decline (-1 or more decrease in rank for both periods - 2000 to 2006 and 2006 to 2013).

One explanation for the high percentage of states $(60 \%)$ displaying no sustained gains or sustained declines is that many of the 30 states had offset gains and losses during the two time periods examined. Twenty-two out of the 50 states (44\%) had offsetting rank gains during 2000 to 2006, followed by rank losses during 2006 to 2013, or rank losses during 2000 to 2006 followed by rank gains during 2006 to 2013. The data indicate that changes in state rank occur due to state-level actions, such as governor and state legislature business tax policy changes, but that these changes are often offset possibly by newly elected governors or newly elected state legislators.

In some particular case examples of states, the offsets are very dramatic:

- $\quad$ Arkansas: A +14 gain in rank from 2000 to 2006 offset during the next seven years from 2006 to 2013 with a rank decline of -16 .

- Louisiana: A -15 loss in rank from 2000 to 2006 offset during the next seven years from 2006 to 2013 with a rank gain of +17 .

- $\quad$ Pennsylvania: A +8 gain in rank from 2000 to 2006 offset during the next seven years from 2006 to 2013 with a rank decline of -7 .

\section{RANK CORRELATION ANALYSIS OF DIFFERENT TIME DURATIONS}

A rank correlation analysis was performed on the SBSI state rankings of 2013 compared with various durations of time periods of gap in years up to 2013. The following rank correlation analysis displayed in Table 2 supports the conclusion that there is a high level of traction with little mobility in ranking over time periods that varied from one to thirteen years. All rank correlations range from 0.79 to 0.97 . The data indicate that little change in rank is possible during one governor term and that very little change in rank is possible during one state legislative term as the rank correlations range from 0.88 to 0.94 for a two- to four-year duration.

Table 2: Rank Correlation Analysis of SBSI State Rankings over Different Time Durations

\begin{tabular}{|l|l|l|}
\hline 0.9684 & correlation 2013 and 2012 & 1-year change \\
\hline 0.8759 & correlation 2013 and 2011 & 3-year change \\
\hline 0.8759 & correlation 2013 and 2010 & 4-year change \\
\hline 0.9393 & correlation 2013 and 2009 & 5-year change \\
\hline 0.9252 & correlation 2013 and 2008 & 6-year change \\
\hline 0.8997 & correlation 2013 and 2007 & 7-year change \\
\hline 0.8500 & correlation 2013 and 2006 & 8-year change \\
\hline 0.8116 & correlation 2013 and 2005 & 9-year change \\
\hline 0.8326 & correlation 2013 and 2004 & 10-year change \\
\hline 0.8224 & correlation 2013 and 2003 & 11-year change \\
\hline 0.7929 & correlation 2013 and 2002 & 12-year change \\
\hline 0.7892 & correlation 2013 and 2001 & 13-year change \\
\hline
\end{tabular}




\section{IMPACT OF GOVERNOR YEARS OF TERM ON CHANGES IN SBSI RANKING}

As of 2013, all states - except New Hampshire (2-year term) and Vermont (2-year term) - have a four-year term for Governor. Both Vermont and New Hampshire are in the category of significant decliners (Vermont ranked 45th out of 50 states with an overall 13-year decline of -9 and New Hampshire ranked $50^{\text {th }}$ out of 50 states with a decline of -16) and both are in the sub-category of sustained decliners (decline of -1 or greater in both time periods 2000 to 2006 and 2006 to 2013). This may lead support to the notion that a governor aiming at improving state ranking on the small business survivability index needs more than just a two-year term.

\section{IMPACT OF GOVERNOR TERM LIMITS ON CHANGES IN SBSI RANKING}

As of 2013, governors of 36 states are subject to various term limits, while the governors of 14 states may serve an unlimited number of times. The governors of New Hampshire and Vermont may serve unlimited two-year terms. The governors in the following states may serve unlimited four-year terms: Connecticut, Idaho, Illinois, Iowa, Massachusetts, Minnesota, New York, North Dakota, Texas, Utah, Washington, and Wisconsin. Table 3 displays the states with unlimited governor terms, the state's rank-ordered SBSI rank change from 2000 to 2013 in Table 1, and the nominal change (+ or -).

Table 3: Impact of Governor Terms Limits on Changes in SBSI Ranking

\begin{tabular}{|l|c|c|c|}
\hline & Decliners & Stable & Gainers \\
\hline New Hampshire (2 yr unlimited terms) & $50^{\text {th }}-16$ & & \\
Vermont (2 yr unlimited terms) & $45^{\text {th }}-9$ & & \\
Connecticut (4 yr unlimited terms) & 40 th -6 & & \\
Idaho (4 yr unlimited terms) & $38^{\text {th }}-5$ & & \\
Illinois (4 yr unlimited terms & $49^{\text {th }}-14$ & \\
Iowa (4 yr unlimited terms) & $44^{\text {th }}-9$ & & \\
Massachusetts(4 yr unlimited terms) & $32^{\text {th }}-4$ & \\
Minnesota (4 yr unlimited terms) & & & \\
New York (4 yr unlimited terms) & 34 th -4 & & $11^{\text {th }}+4$ \\
North Dakota (4 yr unlimited terms) & $35^{\text {th }}-4$ & 3 \\
Texas (4 yr unlimited terms) & & & 3 \\
Utah (4 yr unlimited terms) & & $36^{\text {th }}+2$ & \\
Washington (4 yr unlimited terms) & & $30^{\text {th }}-3$ & \\
Wisconsin (4 yr unlimited terms) & & \\
\hline
\end{tabular}

The state listing breakdown in Table 3 supports the idea of term limits for governors as only three out of fourteen states showed significant gains in rank over the 13 year period of 2000 to 2013 in the small business survivability index, whereas nine out of the fourteen states with an unlimited term for governor showed significant declines over the 13-year period of 2000 to 2013.

\section{CONCLUSIONS}

Despite political candidate rhetoric about promising to bring about business and economic climate improvements by being change agents, the reality is that there is little, if any, sustained change displayed in state rankings over the term or terms of most state governors during the time period examined (2000 to 2013). Upward mobility in SBSI ranking is displayed as hard to achieve, and sustained upward mobility in SBSI ranking over two consecutive six or seven-year periods of time is even more difficult.

A follow-up second study is planned to focus upon those four states - Ohio, New Mexico, Utah, and Arizona - where they had significant sustained improvement ( +2 or more gain) in their SBSI rankings from 2000 to 2013 over both time periods 2000 to 2006 and 2006 to 2013. The focus of this second study will be on identification and discussion of what key changes were made by these states so as to consider policy implications for other states seeking to improve their ranking also on the SBSI. 


\section{AUTHOR INFORMATION}

Dr. P. K. Shukla is an Associate Professor of Management at the Argyros School of Business and Economics at Chapman University. He has served previously as Director of the Leatherby Center for Entrepreneurship and as Vice Chancellor for Entrepreneurship at Chapman University. He has consulted to businesses and has served on boards of directors of organizations in addition to serving on the editorial review board of academic journals. His $\mathrm{Ph} . \mathrm{D}$. is from the University of California-Los Angeles and he has a Master's of Science Degree in Business Administration from the University of Southern California. E-mail: shukla@ chapman.edu (Corresponding author)

Monica Shukla is a Doctoral Candidate at Chapman University and is an Assistant Professor of Business at Brandman University in Irvine, California. Her dissertation focuses upon an examination of best practices in the use of social media by higher education institutions, including an analysis of return on investment measurement approaches. She has served in managerial positions in higher education and has entrepreneurial experience with her own consulting firm. She has Master's Degrees in Human Resources Management and also in Organizational Leadership. She also has a Graduate Certificate in Non-Profit Leadership.

\section{REFERENCES}

1. The Small Business and Entrepreneurship Council (SBE Council). Available at www.sbecouncil.org

2. $\quad$ Keating, R. (2013, April). Business Tax Index 2013: Best to worst state tax systems for entrepreneurship and small business. Published Report of the Small Business Council.

3. Keating, R. Small Business Survival Index. From 2000 to 2012. Published Report of the Small Business Council. 